\title{
Effect of Different Levels of NPK and FYM on Growth and Yield of Potato
}

\author{
Richa Pyasi*, A. K Barholia and R. P. Singh \\ Department of Horticulture, college of Agriculture Gwalior, RVSKVV (M.P), India \\ *Corresponding author
}

\begin{tabular}{|l|}
\hline K e y w o r d s \\
$\begin{array}{l}\text { Kufri chipsona-1, } \\
\text { sowing, Solanum } \\
\text { tuberosum L., } \\
\text { potato }\end{array}$ \\
\hline Article Info \\
\hline $\begin{array}{l}\text { Accepted: } \\
\text { 25 September } 2019 \\
\text { Available Online: } \\
10 \text { October } 2019\end{array}$ \\
\hline
\end{tabular}

\section{A B S T R A C T}

The present experiment was conducted at the, Department of Horticulture, College of Agriculture, RVSKVV, Gwalior (M.P.) during the Rabi season of two consecutive years 2017-18 and 2018-19, to study the response of growth and yield parameters potato crop under different levels of NPK fertilizers and farm yard manure (FYM).The experiment was laid out in Randomized Completely Block Design (RCBD) with three replications and variety under test was potato cultivar Kufri chipsona-1. Growth parameters under observation were plant height, shoots per plant, leaf area $\left(\mathrm{cm}^{2}\right)$, diameter of stem $(\mathrm{cm})$, fresh weight of shoots and roots per plant, were recorded. The findings of present study revealed that among the good response of growth and yield parameters was observed with the advancement in levels of NPK from $50 \%$ upto $100 \%$ NPK at 30, 60 and 90 days after sowing. Highest graded tuber yield, marketable yield (19.9 t/ha), processing yield and highest total yield of $21.1 \mathrm{t} / \mathrm{ha}$ was recorded under treatment $100 \%$ NPK. Whereas among FYM treatments, highest yield of $18.8 \mathrm{t} /$ ha was obtained with treatment (FYM 20 t/ha).

\section{Introduction}

Potato (Solanum tuberosum L.) is a herbaceous annual dicotyledonous plant in which underground stems give rise to tubers. It belongs to the family Solanaceae and it is grown across the world for its edible tubers. Originally it is an important temperate crop, but well adopted for sub-tropical conditions. As compared to cereal crops, potato produces much more dry matter in a shorter cycle
(Singh and Trehan, 1998). This high rate of dry matter production results in large amounts of nutrients removed per unit time, which generally most of the soils are not able to supply. In earlier days, chemical fertilizers were considered as the main source of nutrients for potato crop. However, continuous application of chemical fertilizers leads to nutritional imbalance which can be rectified through the use of organic manures. Therefore to check the effects of inorganic fertilizers and 
farm yard manure (FYM), the present experiment was carried out to study the response of growth and yield parameters potato crop under different levels of NPK fertilizers and FYM.

\section{Materials and Methods}

The experiment was conducted at the, Horticulture research area, Department of Horticulture, College of Agriculture, Rajmata Vijayaraje Scindia Krishi Vishwa Vidyalaya, Gwalior (M.P.) during the Rabi season of two consecutive years 2017-18 and 2018-19. The Experimental site College of Agriculture, Gwalior is situated at $26^{\circ} 13 \mathrm{~N}$ latitude and $78^{\circ}$ 14' E longitudes at an altitude of $211.5 \mathrm{~m}$ from mean sea level in central part of Madhya pradesh and it has a semi-arid subtropical climate. The soil of the experimental field was clay in texture with uniform topography. The treatments comprised of three levels of NPK fertilizers viz., (100\% NPK), (75\%NPK) and $(50 \% \mathrm{NPK})$ and two levels of farm yard manure viz., (FYM10 t/ha), (FYM 20 t/ha) tested on potato cultivar Kufri chipsona-1. The experiment was laid out in Randomized Completely Block Design (RCBD) with three replications. Nitrogen was given in the form of urea. Phophorus and potassium were applied through single super phosphate and muriate of potash, respectively. Pre-planting seed treatment was done with Mancozeb $0.2 \%$ solution. The tubers of uniform size were sown in plots of size $3 \times 3$ $\mathrm{m}$ at a spacing distance of $60 \times 20 \mathrm{~cm}$. The observations for plant growth parameters like plant height, number of shoots per plant, number of leaves per plant, leaf area $\left(\mathrm{cm}^{2}\right)$, diameter of stem $(\mathrm{cm})$, fresh weight of shoots per plant, fresh weight of roots per plant $(\mathrm{g})$, were recorded on five randomly selected plants from each plot of each replication separately. Similarly, observations for yield parameters were taken at the time of harvest to obtain the viz., grade wise yield of tubers(kg/plot), Processing grade tuber yield (T/ha), Marketable tuber yield and Total yield (T/ha) of potato tubers. The grade wise yield of tubers was obtained by sorting out total yield into four grades. The grading was done based on weight basis viz., A (>75 g), B (50$75 \mathrm{~g}), \mathrm{C}(25-50 \mathrm{~g})$ and unmarketable tubers $(<-$ $25 \mathrm{~g})$ and tubers of each grade were weighed separately and graded yield was expressed in kilograms (kg/plot). Processing grade tuber yield (T/ha) was obtained by taking weight of tubers weighing (above $75 \mathrm{~g}$ ). Similarly, Marketable tuber yield (T/ha) $\left(\mathrm{A}^{\prime}+{ }^{\prime} \mathrm{B}+{ }^{\prime} \mathrm{C}\right.$ grade tubers) was obtained by adding yield of "A (>75 g), "B (50-75 g) and "C (25-50g) grade tubers and total yield (T/ha) was obtained as a sum total of all tuber yield obtained from each treatment and each replication at the time of harvest. The data recorded under the study were subjected to statistical analysis as per standard procedure as suggested by Panse and Sukhatme (1985).

\section{Results and Discussion}

\section{Effects of NPK}

Growth of the potato plant was studied (Table1) with respect to plant height $(\mathrm{cm})$, leaves per plant, Per cent emergence, number of shoots per plant, diameter of the stem $(\mathrm{cm})$, leaf area per plant $\left(\mathrm{cm}^{2}\right)$, fresh weight of shoot and root per plant (g), days to haulm cutting and days to harvest (Table-2). There was significant effect of NPK on all the growth parameters. Plant height and number of leaves per plant were increased with advancement of levels of NPK from 50\% upto $100 \%$ NPK at 30, 60 and 90 days after sowing. The above results are in close proximity with the finding of Raghav et al.,(2008), Gavit et al., (2010) and Marthha et al., (2017). Similarly maximum number of shoots per plant and fresh weight of shoot and root per plant $(\mathrm{g})$, was also observed under the treatment $\mathrm{I}_{3}(100 \% \mathrm{NPK})$ while it was recorded lowest in the treatment $\mathrm{I}_{1}(50 \% \mathrm{NPK})$. This 
may be due to higher uptake of nutrients at higher dose of NPK which may have resulted in increased vegetative growth of plants and increased shoots and root weight per plant, similar findings were reported by Kumar et al., (2015) and Jatav et al., (2017).

Yield parameters:-The graded tuber yield increased with increase in level of NPK fertilizers (Table-3).

Similarly, maximum marketable tuber yield (A'+'B+'C grade tubers) and highest yield total tuber yield of tubers was observed in the treatment $(100 \% \mathrm{NPK})$ followed by treatment (75\%NPK).

Response of high grade tubers at high fertilizer rates in this study may be due the good bulking tuber efficiency at this level of NPK. Whereas, treatment (50\% NPK) had resulted in more unmarketable tubers (0-25 g) and gave less yield of large sized tubers per plot as compared to other treatments $(100 \% \mathrm{NPK})$ and treatment $(75 \% \mathrm{NPK})$. Which could be due to less availability of nutrients and hence tubers could not have bulked properly.

These findings are in close association with findings made by Singh et al., (2007) who reported that there was significant increase in production of large sized tubers under fertility level (150 N:150 P:100 K kg/ha), and more number of medium size tubers were obtained from medium fertility level (100 N:100 P: 50 $\mathrm{K} \mathrm{kg} / \mathrm{ha}$ ). Kumar et al., (2011) also disclosed that the crop receiving $100 \%$ NPK was the best treatment capable of affecting yield of different grades (A, B and C) of tubers. Kumar et al., (2015) obtained highest chips grade tubers from potato chipping variety Kufri Chipsona-4 under fertilizer treatment of (100\% NPK). Kumar et al., (2017) obtained the highest marketable tubers yield of (20.86 $\mathrm{kg} / \mathrm{plot})$ total tuber yield $(21.05 \mathrm{~kg} / \mathrm{plot})$ with the application of $100 \% \mathrm{NPK} / \mathrm{ha}$. Similarly, Swaroop et al.,(2018) also concluded that with the application of $100 \%$ NPK a yield of (24.1.t/ha) was obtained in potato.

\section{Effects of FYM}

There was no significant differences noticed among the results shown by both the farm yard manure treatments(FYM $20 \mathrm{t} / \mathrm{ha})$ and (FYM10 t/ha) on various growth parameters of plants(Table-1) and (Table-2), like height of the plant, leaves per plant, number of shoots per plant, diameter of the stem, leaf area and per fresh weight of root and shoot per plant at 30, 60 and 90 days after sowing, which can be due to low quantity of nutrients present in FYM. Similar, results were also reported by Gavit et al., (2010) and Banafar et al., (2005) reported that with the application of 15 ton FYM, maximum fresh weight of shoot per plant $(361.40 \mathrm{~g})$ were recorded.

Whereas, the yield differed among the two FYM levels doses (Table-3). Highest graded tuber yield, marketable tuber yield, processing ('A'grade) yield and total yield was obtained with treatment (FYM 20 t/ha)than with treatment (FYM10 t/ha), which can be due to FYM provided porosity and space in soil for tuber growth and provided nutrients and also facilitated their good absorption leading to increase in increase in more number of large sized tubers and thus increasing their yield. More availability of nutrients supply increased the yield also.

These results are in confirmation with findings of Jaipaul(2011) who found that FYM at 20 $\mathrm{t} /$ ha resulted in highest yield of ' $A$ ' grade tubers (41\%).Kumar t/ha of " $A$ " grade tubers, (11.68 t/ha) of B" grade tubers and (3.41 t/ha) of C" grade tubers yield. Similar findings were also noticed by Khurana and Bhutani (2005) and Sandhu et al., (2010) with the application of $20 \mathrm{t} \mathrm{FYM/} \mathrm{ha.}$ 
Table.1 Effect of different levels of NPK and FYM on growth parameters of Potato.

\begin{tabular}{|c|c|c|c|c|c|c|c|c|c|c|c|}
\hline \multirow[t]{2}{*}{ Treatment } & \multirow{2}{*}{$\begin{array}{c}\begin{array}{c}\text { Plant } \\
\text { emergence } \\
\%\end{array} \\
30 \text { DAS } \\
\end{array}$} & \multicolumn{3}{|c|}{ Plant height (cm) } & \multicolumn{3}{|c|}{$\begin{array}{c}\text { Number of leaves per } \\
\text { plant }\end{array}$} & \multicolumn{2}{|c|}{$\begin{array}{l}\text { Shoots per } \\
\text { plant }\end{array}$} & \multicolumn{2}{|c|}{$\begin{array}{l}\text { Diameter of } \\
\text { stems (cm) }\end{array}$} \\
\hline & & $\begin{array}{c}30 \\
\text { DAS }\end{array}$ & $\begin{array}{c}60 \\
\text { DAS }\end{array}$ & $\begin{array}{c}90 \\
\text { DAS }\end{array}$ & $\begin{array}{c}30 \\
\text { DAS }\end{array}$ & $\begin{array}{c}60 \\
\text { DAS }\end{array}$ & $\begin{array}{c}90 \\
\text { DAS }\end{array}$ & $\begin{array}{c}60 \\
\text { DAS }\end{array}$ & $\begin{array}{c}90 \\
\text { DAS }\end{array}$ & $\begin{array}{c}60 \\
\text { DAS }\end{array}$ & $\begin{array}{c}90 \\
\text { DAS }\end{array}$ \\
\hline $50 \%$ NPK & 85.41 & 19.23 & 40.71 & 52.27 & 20.15 & 42.28 & 65.83 & 3.62 & 4.76 & 1.52 & 3.86 \\
\hline $75 \%$ NPK & 86.33 & 21.92 & 40.7 & 58.93 & 22.1 & 45.09 & 68.04 & 3.8 & 5.31 & 1.58 & 4.07 \\
\hline $100 \% \mathrm{NPK}$ & 88.4 & 23.09 & 45.1 & 58.9 & 23.09 & 43.38 & 72.16 & 4.02 & 5.33 & 1.66 & 4.24 \\
\hline SE(m) & 0.779 & 0.280 & 0.448 & 0.656 & 0.228 & 0.556 & 0.807 & 0.104 & 0.074 & 0.039 & 0.052 \\
\hline CD at 5\% & 2.199 & 0.790 & 1.264 & NS & 0.812 & 0.589 & 0.671 & 0.212 & 0.210 & 0.110 & 0.145 \\
\hline 10 T FYM & 86.04 & 21.5 & $41.4 \varepsilon$ & 58.13 & 21.60 & 44.30 & 67.74 & 3.8 & 5.01 & 1.57 & 4.02 \\
\hline 20 T FYM & 86.4 & 21.7 & 42.88 & 58.60 & 22 & 46.21 & 69 & 3.8 & 5. & 1.61 & 4.09 \\
\hline SE $(m)$ & 0.636 & 0.229 & 0.366 & 0.535 & 0.186 & 0.464 & 0.659 & 0.085 & 0.061 & 0.032 & 4.042 \\
\hline CD at 5\% & NS & NS & NS & NS & 0.592 & 0.614 & 0.714 & NS & 0.171 & NS & NS \\
\hline
\end{tabular}

(DAS- days after sowing, NPK-Nitrogen, Phosphorus, Potassium)

Table.2 Effect of different levels of NPK and FYM on growth parameters of Potato.

\begin{tabular}{|c|c|c|c|c|c|c|c|c|c|c|}
\hline \multirow[t]{2}{*}{ Treatment } & \multirow[t]{2}{*}{$\begin{array}{l}\text { Days to } \\
\text { Harvest }\end{array}$} & \multicolumn{3}{|c|}{$\begin{array}{c}\text { Leaf area per plant } \\
\left(\mathrm{cm}^{2}\right)\end{array}$} & \multicolumn{3}{|c|}{$\begin{array}{l}\text { Average fresh weight of } \\
\text { roots }\end{array}$} & \multicolumn{3}{|c|}{$\begin{array}{l}\text { Average Fresh weight of } \\
\text { Shoots }\end{array}$} \\
\hline & & $\begin{array}{c}30 \\
\text { DAS }\end{array}$ & $\begin{array}{c}60 \\
\text { DAS }\end{array}$ & $\begin{array}{c}90 \\
\text { DAS }\end{array}$ & $\begin{array}{c}30 \\
\text { DAS }\end{array}$ & $\begin{array}{c}60 \\
\text { DAS }\end{array}$ & $\begin{array}{c}90 \\
\text { DAS }\end{array}$ & $\begin{array}{c}30 \\
\text { DAS }\end{array}$ & $\begin{array}{c}60 \\
\text { DAS }\end{array}$ & $\begin{array}{c}90 \\
\text { DAS }\end{array}$ \\
\hline $50 \%$ NPK & 118.4 & 140.3 & 321.1 & 405.5 & 3.92 & 7.9 & 12.11 & 82.93 & 155.6 & 182.8 \\
\hline $75 \%$ NPK & 118.5 & 145.4 & 316.1 & 414.0 & 4.40 & 9.07 & 13.56 & 85.75 & 155.4 & 191.2 \\
\hline $100 \%$ NPK & 117.8 & 148.6 & 343.0 & 418.2 & 4.83 & 9.22 & 15.21 & 88.9 & 166.6 & 197.03 \\
\hline SE(m) & 0.373 & 1.35 & 3.118 & 4.04 & 0.077 & 0.114 & 0.166 & 0.904 & 1.607 & 1.971 \\
\hline CD at $5 \%$ & NS & 0.312 & 0.259 & NS & 0.217 & 0.323 & 0.469 & 7.142 & NS & 5.561 \\
\hline 10 T FYM & 118.4 & 143.8 & 323.8 & 410.9 & 4.27 & 7.97 & 13.26 & 84.87 & 158.0 & 188.04 \\
\hline 20 T FYM & 118.56 & 144.9 & 329.7 & 414.2 & 4.50 & 9.07 & 13.99 & 86.8 & 162.4 & 192.7 \\
\hline SE(m) & 0.305 & 1.109 & 2.54 & 3.29 & 0.063 & 0.093 & 0.136 & 0.738 & 1.312 & 1.609 \\
\hline CD at $5 \%$ & NS & NS & NS & NS & 0.177 & 0.613 & 0.383 & $\mathrm{NS}$ & NS & 4.541 \\
\hline
\end{tabular}

(DAS- days after sowing, NPK-Nitrogen, Phosphorus, Potassium) 
Table.3 Effect of levels of NPK and FYM on yield parameters of Potato.

\begin{tabular}{|c|c|c|c|c|c|c|c|}
\hline \multirow[t]{2}{*}{ Treatments } & \multirow{2}{*}{$\begin{array}{l}\text { Processing } \\
\text { grade } \\
\text { tuber yield } \\
\text { (T/ha) }\end{array}$} & \multicolumn{4}{|c|}{ Grade wise tuber yield (kg/plot) } & \multirow{2}{*}{$\begin{array}{c}\text { Marketable } \\
\text { tuber yield } \\
\text { (T/ha) }\end{array}$} & \multirow{2}{*}{$\begin{array}{c}\text { Total yield } \\
\text { (T/ha) }\end{array}$} \\
\hline & & ' $A$ ' grade & ' $\mathrm{B}$ ' grade & $\begin{array}{c}\text { 'C' } \\
\text { grade }\end{array}$ & $\begin{array}{c}\text { Unmarke } \\
\text { table } \\
\text { yield }\end{array}$ & & \\
\hline $50 \%$ NPK & 4.70 & 4.25 & 4.55 & 4.29 & 1.35 & 14.60 & 16.17 \\
\hline $75 \%$ NPK & 6.12 & 5.54 & 5.45 & 4.20 & 1.13 & 16.86 & 18.20 \\
\hline $100 \%$ NPK & 8.20 & 7.38 & 6.73 & 3.90 & 0.84 & 19.91 & 21.02 \\
\hline SE(m) & 0.091 & 0.081 & 0.113 & 0.075 & 0.048 & 0.165 & 0.212 \\
\hline CD at $5 \%$ & 0.257 & 0.227 & 0.318 & 0.211 & 0.099 & 0.466 & 0.502 \\
\hline 10 T FYM & 6.03 & 5.45 & 5.33 & 4.1 & 1.16 & 16.59 & 17.96 \\
\hline 20 T FYM & 6.6 & 6.01 & 5.83 & 4.09 & 1.06 & 17.71 & 18.8 \\
\hline SE(m) & 0.074 & 0.066 & 0.092 & 0.061 & 0.039 & 0.135 & 0.173 \\
\hline CD at $5 \%$ & 0.210 & 0.186 & 0.259 & NS & NS & 0.380 & 0.410 \\
\hline
\end{tabular}

(DAS- days after sowing, NPK-Nitrogen, Phosphorus, Potassium)

References

Banafar, R. N. S. Billore, M. and Kushwah, S. S. 2005. Integrated plant nutrition approaches for potato. Potato J. 32: 34.

Gavit, Chandrakala.,Varsha, A.(2010). The influence of organic manures and inorganic fertilizers on growth and yield of potato. Contemporary Research in India (ISSN 2231-2137): Vol.6: Issue: 2.

Jaipaul,. Sharma, Sanjeev and, Sharma,K.(2011). Effect oforganic fertilizers on growth, yield and quality of potato under rainfed conditions of central Himalayan region of Uttarkhand. Potato J., 38(2):176-181.

Jatav, A. S., Kushwah,S. S. and Naruka,I.S. (2017). Performance of Potato Varieties for Growth, Yield, Quality and Economics under Different Levels of Nitrogen. Advances in Research 9(6): 1-9.

Khurana,S.C and Bhutani,R.D (2005).Effect of FYM, biofertilizers and inorganic fertilizers on potato. The Indian Potato Association.vol:32, No.3-4, pg:242.

Kumar,Parveen., Kumar, Rajeev., Kumar, Dinesh., Singh, Sukhwinder.,Sandhu, K.S and. Singh, B.P.(2015).Fertilizer management of potato (Solanum tuberosum) variety KufriFrysonafor higher yield, good fry quality, profitability and Storability. Ann. Agric. Res. New Series Vol. 36 (2): 191-199.

Kumar, M., Baishya, L. K., Ghosh, D. C. and Gupta, V. K. (2011). Yield and quality of potato (Solanum tuberosum) tubers as influenced by nutrient sources under rainfed condition of Meghalaya. Indian Journal of Agronomy.56(3):260-266.

Kumar, Vikas., Sharma, Saurabh., Malik Asheesh (2017). Study thedifferent level of Nitrogen and Phosphorus on growth, yield of Potato Crop (Solanum tuberosum L.)International Journal of Scientific \& Engineering Research 8(7), pp 101-107.

Marthha, D., Sahu, G. S.,Sahu, P. and Mishra, N. (2017). Performance of potato cv. 
kufriashoka as influenced by graded levels of N, P and K. Plant Archives. 17(2): 1435-1438.

Panse VG, Sukhatme PV. Statistical methods, for agricultural workers. Fourth edition. ICAR Publication, New Delhi; 1985.

Raghav, M., Kumar T. and Kamal, S. (2008). Effect of organic sources on growth, yield and quality of potato. Annals of Horticulture.1(1): 67-70.

Sandhu KS, Chinna GS, Marwaha RS, Kumar $P$ and Pandey SK. 2010. Effect of nitrogen fertilization on yield and chipping quality of processing varieties grown in cooler north indian plains, Potato Journal, 37 (3 - 4): 143-150.

Singh, S. N., Singh, B.P., Singh, O.P., Singh, R. and Singh, R.K. 2007.Effect of nitrogen application in conjunction with bio-inoculants on the growth, yield and quality of potato under indogengetic plain region. Potato Journal.34 (1-2): 103-104.

Singh, J.P. and S.P.Trehan. (1998). Balanced fertilization to increase the yield of potato. In: Proceedings of the IPIPRII-PAU Workshop on: Balanced Fertilization in Punjab Agriculture, held at Punjab Agricultural University, Ludhiana, India, 15-16 pp. 129-139.

Swaroop,Narendra.,P YongnyuPhom,. David, Arun Alfred and Tarence Thomas (2018).Effect of different levels of NPK and FYM on the physicochemical properties of soil growth and yield of potato (Solanum tuberosumL.) cv. KufriBadshah. International Journal of Chemical Studies; 6(4): 631-636.

\section{How to cite this article:}

Richa Pyasi, A. K Barholia and Singh, R. P. 2019. Effect of Different Levels of NPK and FYM on Growth and Yield of Potato. Int.J.Curr.Microbiol.App.Sci. 8(10): 2713-2718. doi: https://doi.org/10.20546/ijcmas.2019.810.312 